\title{
Positive Career Attitudes Effect on Happiness and Life Satisfaction by Master Students and Graduates
}

\author{
Senad Karavdic, Michèle Baumann \\ Institute Health \& Behaviour, Integrative Research Unit on Social and Individual Development (INSIDE), \\ University of Luxembourg, Walferdange, Luxembourg \\ Email: Michèle.baumann@uni.lu
}

Received May 2014

\begin{abstract}
Background: Happiness and life satisfaction are well-known indicators. However, there has been little contribution by the scientific community on the positive career attitudes of master students and graduates. In an effort to provide deeper empirical understanding, the relationships between positive career attitudes, health satisfaction, financial situation and happiness and life satisfaction among master students and graduates were analyzed. Method: A link of online questionnaire was sent by mail to all students which independently of their social economic status obtained a financial aid from the government of Luxembourg, and to all master graduates (ex-students) who have been finished with their courses for one year. The data was analyzed using bivariate tests, correlation and multiple linear regression models. Result: 455 voluntary postgraduate/master students vs. 144 graduates participated. Students were younger than the graduates (mean age 26 vs. 29 years). Majority was female and had Luxembourgish nationality. Most graduates had a job and lived with their parents. Luxembourg natives were happier, and those who were living with their parents showed higher life satisfaction. For both samples, self-rated health satisfaction was positively associated with happiness and life satisfaction. For the students, the higher career adaptability and career optimism are, the better the happiness and life satisfaction will be. The higher the perception of the household financial situation is, the better the happiness will be. For graduates, the higher career optimism contributed to the better happiness. Conclusion: Happiness and life satisfaction of master students and graduates were affected, related to socioeconomic and perceived health difficulties, and career attitudes. Those indicators could be used routinely to monitor the situation of young people over time and their needs in terms of adaptability and optimism capabilities, which should be appropriately treated. These findings may help with the development of university and post university interventions aimed at improving happiness and life satisfaction among postgraduate students and ex-students.
\end{abstract}

\section{Keywords}

University Students, Graduates, Positive Career Attitudes, Happiness, Life Satisfaction 


\section{Introduction}

Happiness and Life Satisfaction are, along with the economic factors of a country, well-known indicators used in the estimation of a populations' subjective well-being and their quality of life [1]. The understanding of researchers is that happiness and life satisfaction are identical and can be used interchangeably [2]. Others state that there is a difference between life satisfaction and happiness showing that they are related but cannot be treated as identical and the same latent variable [3]. Happiness can be understood as an emotional feeling of wanting more [4], a presence of positive affect and an absence of negative one, although satisfaction can be seen as a cognitive evaluation or judgment of one's life and could be perceived as a discrepancy between aspiration and achievement [5]. In spite of this, Gundelach \& Kreiner's (2004) analysis of the data from the European Value Survey in nine industrialized countries has shown that happiness and life satisfaction are two different but related socio-economic determinants [6].

It is obvious that higher level of university education is associated with low levels of unemployment [7] despite the fact jobs in Europe requiring a University achievement, a graduate and postgraduate degree were further represented by persons belonging to the later age group in retirement [8]. This professional landscape is characterized by increasing economic insecurity [9] which may be perceived by university students as a period of uncertainty and fear [10]. Not being able to find a job and managing that fact by accepting or possibly accepting a job below their qualifications are the real life preoccupations of students and graduates with postgraduate studies. In addition, during the late pre-academic time, young students are confronted with examinations and coursework deadlines at the expense of their career outcome. They may display passiveness in their career attitudes neglecting, career planning allowing them on one hand to make a series of steps for the best transition and on the other hand develop a series of strategies to face the challenge of a weakened job market [11]. University students may have socioeconomic difficulties handling their substantial needs [12]. Everyday stress causes the development of strategies aimed to cope with these problems [13], which may have an impact on their academic performance, being more prone to depressive situations [14], lower general and mental health and more hazard health behaviour [15].

Career adaptability and career optimism attitudes are important triggers throughout one's career [16]. Career adaptability can be understood as an individual's capability to anticipate a possible novel situation and get ready in advance for change by acquiring new abilities and strengthening to make a series of successful transitions where the labour market is in constant change [17]. Career optimism is the perception to which individuals have a positive disposition about their future career expectations and comfort in performing career planning tasks [18]. Researchers have analyzed the relationships between career attitudes and psychosocial factors that could have an impact on life satisfaction and happiness. However no studies have considered a postgraduate group during their transitional period. The aspects of adaptability were negatively associated to concerns, general anxiety and fear about one's future career [19]. In contrast, the facet of optimism has been linked to a health-related adjustment [20], and a positive attitude toward self and one's life in general [21]. Persons optimistic about their career have reported greater comfort with their education and career-related plans, as well as engagement in activities that enhance their career insight [18].

In spite of this "The Centre for Documentation and Information on Higher Education" (CEDIES), in Luxembourg - the smallest country in Europe (531,400 habitants, $2600 \mathrm{~km}^{2}$ ) with one of the highest gross domestic product (GDP) per inhabitant [22] provides a financial aid intended for students, prospective students, and people who wish to return to higher education in Luxembourg and internationally (EU and no-EU). During and official term of studies, each semester, every student who is a resident can benefit from a study grant regardless the income of the parents/relatives or place/country. It's also independent of the nationality, age and/or type of study.

During this period young adults may be vulnerable and they may feel disoriented and unduly affected by their social-economic and employment situation which may have an impact on their happiness and life satisfaction, interestingly, their contribution to the career attitudes of master students and graduates has not been well explored. Happiness and life satisfaction may play an important role in emerging adulthood among university individuals preparing for the transition to work. In this research, we proposed to compare students and graduates who have been finished with their studies for one year, because this transitional time could be considered as a period of adjustment that can be both challenging and exciting. In an effort to provide deeper empirical understanding, our objective was to analyze the relationships between career attitudes, perceived health satisfaction, 
financial situation and happiness and life satisfaction among master students and graduates.

\section{Method}

\subsection{Population}

All postgraduate/master students and first year graduates (ex-students) registered in 2012 and 2013 at the Centre for Documentation and Information on Higher Education” (CEDIES) which independently of their social economic status obtained a financial aid from the government of Luxembourg, were invited by mail to the survey.

\subsection{Data Collection}

Via information flyer containing information about the aims of the study and a link to the survey. The participants could directly access the anonymous online questionnaire with a choice of language (French or English).

\subsection{Measurement Instruments}

Four groups of variables were gathered:

\subsubsection{Dependent Variables}

Happiness single-item (e.g., How happy do you feel? 1 = not at all happy; 10 = very happy)

Life satisfaction single-item (e.g. How would you rate your life satisfaction? $1=$ not at all satisfied, $10=$ very satisfied).

\subsubsection{Positive Career Attitudes}

Using Career Futures Inventory [18] we selected with a factorial analysis:

Career adaptability (4 items; Cronbach's alpha 0.80) (e.g. I am good at adapting to new work settings; I can adapt to change my career plans; I can overcome potential barriers that may exist in my work; I can adapt to change in the world of work) ( 1 = strongly disagree; 5 = strongly agree).

Career optimism (4 items; Cronbach's alpha 0.74) (e.g. I get excited when I think about my career; I understand my work-related interests; I am unsure of my future career success; I am eager to pursue my career dreams $)(1$ = strongly disagree; $5=$ strongly agree $)$.

\subsubsection{Health Satisfaction}

Self-rated health satisfaction [23] was measured with single-item (e.g. Are you satisfied with your health? $1=$ not at all satisfied; 5 = very satisfied).

\subsubsection{Demographic Characteristics}

Age, sex, nationality (Luxembourg/other nationality), parents' education level (higher/lower then Bachelor), type of lodging (with parents/other situation), job (yes/no) and perceived financial household situation (e.g. How do you evaluate the financial situation of your household? $(1=$ very poor; 6 = very good $)$.

\subsection{Statistical Analysis:}

For each variable, all scores were calculated so that a higher score represented a better level. The student and graduate groups were compared by means of Chi-square tests and Student's t-tests. Bivariate correlations were used for association analyses between the variables. Significant relationships were used in multiple models. Finally, a moderate regression with the two groups as the categorical variables was carried out to compare the slope parameters.

\section{Results}

\subsection{Socio-Economic and Health Status}

A total of 455 students vs. 144 graduates' volunteers participated. The students were younger than the graduates (mean age 26 vs. 29 years). Majority were female and natives of Luxembourg. Mostly graduates have a job and 
lived with their parents (Table 1).

\subsection{Relations between Socio-Economic, Positive Career Attitudes, Health Satisfaction and Happiness and Life Satisfaction}

Self-rated health satisfaction, career adaptability and career optimism scores were positively related, indicating better life satisfaction and happiness for better health satisfaction and higher positive career attitudes. With the happiness score, perceived financial situation was positively linked, for the students, and nationality was negatively associated, for graduates (Table 2).

\subsection{Associations between Socio-Economic, Positive Career Attitudes, Health Satisfaction and Happiness and Life Satisfaction}

The separated models of multiple regressions explained happiness factor (adjusted R-Square) by 31.0\% vs. 40.6\% of variance for students and life satisfaction by $32.8 \%$ vs. $24.8 \%$, respectively for graduates.

Luxembourger natives were happier, and those who were living with their parents showed higher life satisfaction. For both samples, health satisfaction was positively associated with happiness and life satisfaction scores.

For the students, the higher the career adaptability and career optimism scores, the better the happiness and self-rated life satisfaction rating. The higher the financial household situation was perceived, the better the happiness score. For the graduates, higher career optimism contributed to better happiness score (Table 3).

\section{Discussion}

The overall socio-economic profiles of the two volunteer groups differed, the students were younger, less of them had a job and only a few lived with their parents. Students' perception of financial situation was associated

Table 1. Socio-economic and health status. \% or mean and standard deviation (SD).

\begin{tabular}{|c|c|c|c|}
\hline & $\begin{array}{c}\text { Students } \\
\mathrm{N}=455\end{array}$ & $\begin{array}{c}\text { Graduates } \\
N=149\end{array}$ & $p^{1}$ \\
\hline $\begin{array}{l}\text { Dependant Variables } \\
\text { Happiness [1]-[10] } \\
\text { Life Satisfaction [1]-[10] }\end{array}$ & $\begin{array}{l}7.8(1.7) \\
8.0(1.7)\end{array}$ & $\begin{array}{l}7.6(1.7) \\
7.7(1.6)\end{array}$ & $\begin{array}{l}0.071 \\
0.262\end{array}$ \\
\hline $\begin{array}{l}\text { Age: mean (SD) } \\
{[\text { min ; max] }}\end{array}$ & $\begin{array}{c}26.4(5.4) \\
{[20 ; 59]}\end{array}$ & $\begin{array}{c}29.8(6.8) \\
{[23 ; 56]}\end{array}$ & $0.000^{* * *}$ \\
\hline $\begin{array}{l}\text { Gender } \\
\text { Male } \\
\text { Female }\end{array}$ & $\begin{array}{l}40.6 \\
59.4\end{array}$ & $\begin{array}{l}59.6 \\
40.4\end{array}$ & $0.000^{* * *}$ \\
\hline $\begin{array}{c}\text { Nationality } \\
\text { Luxembourger } \\
\text { Other }\end{array}$ & $\begin{array}{l}67.2 \\
32.8\end{array}$ & $\begin{array}{l}58.6 \\
41.4\end{array}$ & $0.005^{* *}$ \\
\hline $\begin{array}{c}\text { Parents education level (>Bachelor) } \\
\text { Father } \\
\text { Mother }\end{array}$ & $\begin{array}{l}49.2 \\
40.0\end{array}$ & $\begin{array}{l}48.7 \\
41.7\end{array}$ & $\begin{array}{l}0.850 \\
0.530\end{array}$ \\
\hline $\begin{array}{l}\text { Job } \\
\text { Yes } \\
\text { No }\end{array}$ & $\begin{array}{l}26.9 \\
73.1\end{array}$ & $\begin{array}{l}68.5 \\
31.5\end{array}$ & $0.000^{* * *}$ \\
\hline Perceived financial situation [1]-[6] & $4.3(1.09)$ & $4.6(1.14)$ & 0.087 \\
\hline $\begin{array}{c}\text { Type of lodging (With parents) } \\
\text { Yes } \\
\text { No }\end{array}$ & $\begin{array}{l}20.9 \\
79.1\end{array}$ & $\begin{array}{l}40.4 \\
59.6\end{array}$ & $0.000^{* * *}$ \\
\hline Self-rated health Satisfaction [1]-[5] & $3.9(0.9)$ & $4.1(0.7)$ & 0.096 \\
\hline $\begin{array}{l}\text { Positive Career Attitudes } \\
\text { Adaptability [1]-[5] } \\
\text { Optimism [1]-[5] }\end{array}$ & $\begin{array}{l}4.0(0.6) \\
3.8(0.7)\end{array}$ & $\begin{array}{l}4.1(0.6) \\
3.7(0.6)\end{array}$ & $\begin{array}{l}0.674 \\
0.425\end{array}$ \\
\hline
\end{tabular}

${ }^{1}$ Significant p-value: ${ }^{*} \mathrm{p}<0.05 ;{ }^{* *} \mathrm{p}<0.01 ;{ }^{* * *} \mathrm{p}<0.001$. 
Table 2. Relationships between socio-economic, career attitudes, health satisfaction and Happiness and Life satisfaction (bivariate tests) - correlation coefficients (Pearson's correlation).

\begin{tabular}{|c|c|c|c|c|c|c|c|c|c|}
\hline & & \multicolumn{4}{|c|}{ Happiness [1]-[10] } & \multicolumn{4}{|c|}{ Life Satisfaction [1]-[10] } \\
\hline & & $\begin{array}{c}\text { Students } \\
\text { Mean }\left(\mathrm{SE}^{1}\right)\end{array}$ & $\mathrm{p}^{2}$ & $\begin{array}{l}\text { Graduates } \\
\text { Mean }\left(\mathrm{SE}^{1}\right)\end{array}$ & $\mathrm{p}^{2}$ & $\begin{array}{c}\text { Students } \\
\text { Mean }\left(\mathrm{SE}^{1}\right)\end{array}$ & $\mathrm{p}^{2}$ & $\begin{array}{l}\text { Graduates } \\
\text { Mean }\left(\mathrm{SE}^{1}\right)\end{array}$ & $\mathrm{p}^{2}$ \\
\hline \multirow[t]{2}{*}{ Gender } & Male & $7.69(0.141)$ & 0.203 & $7.42(.214)$ & 0.685 & $7.86(0.129)$ & 0.430 & $8.16(0.179)$ & 0.125 \\
\hline & Female & $7.92(0.112)$ & & $7.57(.279)$ & & $7.99(0.108)$ & & $7.67(0.278)$ & \\
\hline \multirow[t]{2}{*}{ Nationality } & Lux & $7.78(0.110)$ & 0.450 & $7.83(.077)$ & $0.043^{*}$ & $7.98(0.100)$ & 0.489 & $8.04(0.206)$ & 0.548 \\
\hline & Other & $7.92(0.136)$ & & $7.78(.208)$ & & $7.86(0.140)$ & & $7.85(0.236)$ & \\
\hline \multicolumn{10}{|l|}{$\begin{array}{l}\text { Parents } \\
\text { Education }\end{array}$} \\
\hline Father & $\begin{array}{l}<\text { Bachelor } \\
>\text { Bachelor }\end{array}$ & $\begin{array}{l}7.72(0.124) \\
7.91(0.123)\end{array}$ & 0.276 & $\begin{array}{l}7.39(.244) \\
7.59(.226)\end{array}$ & 0.551 & $\begin{array}{l}7.81(0.116) \\
8.05(0.116)\end{array}$ & 0.137 & $\begin{array}{l}7.85(0.230) \\
8.09(0.202)\end{array}$ & 0.441 \\
\hline Mother & $\begin{array}{l}<\text { Bachelor } \\
>\text { Bachelor }\end{array}$ & $\begin{array}{l}7.90(0.104) \\
7.68(0.156)\end{array}$ & 0.224 & $\begin{array}{l}7.38(.246) \\
7.60(.214)\end{array}$ & 0.529 & $\begin{array}{l}7.93(0.104) \\
7.91(0.136)\end{array}$ & 0.924 & $\begin{array}{l}7.93(0.225) \\
8.00(0.204)\end{array}$ & 0.815 \\
\hline \multirow{2}{*}{\multicolumn{2}{|c|}{$\begin{array}{c}\text { With Parents } \\
\text { Yes } \\
\text { No }\end{array}$}} & $\begin{array}{l}7.62(0.192) \\
7.86(0.099)\end{array}$ & 0.277 & $\begin{array}{l}7.29(.237) \\
7.73(.220)\end{array}$ & 0.184 & $\begin{array}{l}8.05(0.153) \\
7.89(0.097)\end{array}$ & 0.417 & $\begin{array}{l}7.57(0.259) \\
8.26(0.190)\end{array}$ & $0.028^{*}$ \\
\hline & & $\begin{array}{c}\text { Correlation }^{3} \\
\text { coefficient }\end{array}$ & $\mathrm{p}^{2}$ & $\begin{array}{c}\text { Correlation }^{3} \\
\text { coefficient }\end{array}$ & $\mathrm{p}^{2}$ & $\begin{array}{c}\text { Correlation }^{3} \\
\text { coefficient }\end{array}$ & $\mathrm{p}^{2}$ & $\begin{array}{c}\text { Correlation }^{3} \\
\text { coefficient }\end{array}$ & $\mathrm{p}^{2}$ \\
\hline \multicolumn{2}{|c|}{ Happiness score } & - & - & - & - & 0.819 & $<0.001^{* * *}$ & 0.639 & $<0.001^{* * *}$ \\
\hline \multicolumn{2}{|c|}{ Life Satisfaction score } & 0.819 & $<0.001^{* * *}$ & 0.639 & $<0.001^{* * *}$ & - & - & - & - \\
\hline \multicolumn{2}{|c|}{ Age (years) } & 0.000 & 0.480 & -0.410 & 0.800 & 0.000 & 0.000 & -0.100 & 0.283 \\
\hline \multicolumn{2}{|c|}{$\begin{array}{l}\text { Perceived financial } \\
\text { situation }\end{array}$} & 0.154 & $0.004^{*}$ & 0.114 & 0.227 & 0.230 & $<0.000^{* * *}$ & 0.086 & 0.356 \\
\hline \multicolumn{2}{|c|}{$\begin{array}{l}\text { Self-rated health } \\
\text { satisfaction }\end{array}$} & 0.425 & $<0.001^{* * *}$ & 0.454 & $<0.001^{* * *}$ & 0.494 & $<0.001^{* * *}$ & 0.327 & $<0.001^{* * *}$ \\
\hline \multicolumn{10}{|c|}{$\begin{array}{l}\text { Positive Career } \\
\text { attitudes }\end{array}$} \\
\hline Adap & ability & 0.337 & $<0.001^{* * *}$ & 0.272 & $0.003^{*}$ & 0.279 & $<0.001^{* * *}$ & 0.214 & $0.021^{*}$ \\
\hline Opt & mism & 0.338 & $<0.001^{* * *}$ & 0.341 & $<0.001^{* * *}$ & 0.291 & $<0.001^{* * *}$ & 0.243 & $0.008^{* * *}$ \\
\hline
\end{tabular}

${ }^{1}$ Std. Error; ${ }^{2}$ Significant p-value: ${ }^{*} \mathrm{p}<0.05 ;{ }^{* *} \mathrm{p}<0.01 ;{ }^{* * *} \mathrm{p}<0.001 ;{ }^{3}$ Pearson's correlation.

with greater happiness. In contrast, for the graduate group, those who had a job were happier and had a greater life satisfaction. Majority lived with their parents which predicted better life satisfaction. This result confirms the current situation faced by many young people, namely a prolonged time of living in the parental home while three quarters had a job. This finding may indicate the difficulty of the situation that faces young graduates, in particular related to economical insecurity and job status that do not cover the needs of the new generation and do not allow them to think towards the future by taking their autonomy.

Happiness and life satisfaction scores were not different for students and graduates. Considering the literature, life satisfaction was higher for students and slightly lower for graduates (8.0/10 and 7.7/10, respectively), than the national happiness (in 2012, 7.6 /10) and life satisfaction indicator in Luxembourg (in 2012, 7.7/10) [24], which was higher than the average European (happiness 7.6 for EU-27 and life satisfaction 7.1 for EU-27) [1]. But when we considered the age category 25 to 34 years, happiness and life satisfaction (7.2/10 and 7.6/10, respectively) were higher in both our groups than in the European panel. In the same line, the levels of the tertiary education achievement, (7.3/10 and 7.6/10 respectively) [1] were also higher for our students and graduates (8.0/10 and 7.7/10, respectively). This is not a surprise because high education level has been valorised by policies during Bologna Process and European governments as an enhancing factor of the sustainable employability of young academic people. Indeed anticipated university success may provide students with more ambitions to reach a higher social status and more expectations for their career. 
Table 3. Associations of career adaptability and career optimism on happiness and life satisfaction by students and graduates.

\begin{tabular}{|c|c|c|c|c|c|c|c|c|c|c|c|}
\hline & & \multicolumn{5}{|c|}{ Happiness [1]-[10] } & \multicolumn{5}{|c|}{ Life Satisfaction [1]-[10] } \\
\hline & & $b^{1}$ & $\mathrm{L95}^{4}$ & $\mathrm{U95}^{4}$ & $\mathrm{SE}^{3}$ & $\mathrm{p}^{2}$ & $b^{1}$ & $\mathrm{L95}^{4}$ & $\mathrm{U95}^{4}$ & $\mathrm{SE}^{3}$ & $\mathrm{p}^{2}$ \\
\hline \multicolumn{12}{|l|}{ STUDENTS } \\
\hline & Intercept & 0.055 & -1.676 & 1.785 & 0.880 & 0.950 & 0.686 & -0.926 & 2.299 & 0.82 & 0.403 \\
\hline \multicolumn{12}{|l|}{$\begin{array}{c}\text { Positive Career } \\
\text { attitudes }\end{array}$} \\
\hline Adaptability & {$[4]-[20]$} & 0.647 & 0.374 & 0.920 & 0.139 & $0.000^{* * *}$ & 0.467 & 0.211 & 0.723 & 0.13 & $0.000^{* * *}$ \\
\hline Optimism & {$[4]-[20]$} & 0.556 & 0.330 & 0.783 & 0.086 & $0.000^{* * *}$ & 0.435 & 0.223 & 0.647 & 0.108 & $0.000^{* * * *}$ \\
\hline $\begin{array}{l}\text { Self-rated health } \\
\text { Satisfaction }\end{array}$ & {$[1]-[5]$} & 0.647 & 0.374 & 0.920 & 0.139 & $0.000^{* * *}$ & 0.700 & 0.542 & 0.857 & 0.080 & $0.000^{* * *}$ \\
\hline Job & No (vs. Yes) & -0.101 & -0.475 & 0.274 & 0.190 & 0.597 & 0.033 & -0.317 & 0.383 & 0.178 & 0.853 \\
\hline Age & & -0.007 & -0.039 & 0.025 & 0.016 & 0.664 & -0.003 & -0.033 & 0.027 & 0.015 & 0.841 \\
\hline Gender & Male (vs. Fe) & -0.199 & -0.514 & 0.115 & 0.160 & 0.214 & -0.126 & -0.419 & 0.168 & 0.149 & 0.401 \\
\hline Nationality & $\begin{array}{c}\text { Lux } \\
\text { (vs. other) }\end{array}$ & 0.031 & -0.301 & 0.362 & 0.169 & 0.856 & 0.170 & -0.14 & 0.480 & 0.158 & 0.281 \\
\hline Type of lodging & $\begin{array}{l}\text { With parents } \\
\text { (vs. other) }\end{array}$ & 0.125 & -0.258 & 0.508 & 0.195 & 0.521 & -0.129 & -0.486 & 0.227 & 0.181 & 0.476 \\
\hline $\begin{array}{l}\text { Perceived household } \\
\text { financial situation }\end{array}$ & {$[1]-[6]$} & 0.200 & 0.057 & 0.343 & 0.073 & $0.006^{* *}$ & 0.251 & -0.486 & 0.227 & 0.181 & 0.476 \\
\hline \multicolumn{12}{|l|}{ GRADUATES } \\
\hline & Intercept & 0.558 & -2.572 & 3.688 & 1.577 & 0.724 & 3.685 & 0.264 & 7.107 & 1.724 & $0.035^{*}$ \\
\hline \multicolumn{12}{|l|}{$\begin{array}{c}\text { Positive Career } \\
\text { attitudes }\end{array}$} \\
\hline Adaptability & {$[4]-[20]$} & 0.105 & -0.402 & 0.613 & 0.256 & 0.681 & 0.270 & -0.293 & 0.833 & 0.284 & 0.343 \\
\hline Optimism & {$[4]-[20]$} & 0.601 & 0.146 & 1.056 & 0.229 & $0.010^{* *}$ & 0.244 & -0.263 & 0.751 & 0.256 & 0.342 \\
\hline $\begin{array}{l}\text { Self-rated Health } \\
\text { Satisfaction }\end{array}$ & {$[1]-[5]$} & 1.025 & 0.628 & 1.422 & 0.200 & $0.000^{* * *}$ & 0.701 & 0.26 & 1.143 & 0.222 & $0.002^{* *}$ \\
\hline Job & No (vs. Yes) & -0.757 & -1.342 & -0.172 & 0.295 & $0.012^{*}$ & -0.701 & -1.353 & -0.050 & 0.328 & $0.035^{*}$ \\
\hline Age & & -0.018 & -0.062 & 0.025 & 0.022 & 0.403 & -0.035 & -0.083 & 0.013 & 0.024 & 0.146 \\
\hline Gender & $\begin{array}{c}\text { Male } \\
\text { (vs. Female) }\end{array}$ & -0.035 & -0.584 & 0.515 & 0.277 & 0.901 & 0.480 & -0.13 & 1.091 & 0.308 & 0.122 \\
\hline Nationality & $\begin{array}{c}\text { Lux } \\
\text { (vs. other) }\end{array}$ & 0.781 & -1.342 & -0.172 & 0.295 & $0.012^{*}$ & 0.261 & -0.359 & 0.880 & 0.312 & 0.406 \\
\hline Type of lodging & $\begin{array}{l}\text { With parents } \\
\text { (vs. other) }\end{array}$ & 0.566 & -0.032 & 1.164 & 0.301 & 0.063 & 0.779 & 0.112 & 1.445 & 0.336 & $0.023^{*}$ \\
\hline $\begin{array}{l}\text { Perceived household } \\
\text { financial situation }\end{array}$ & {$[1]-[6]$} & 0.027 & -0.229 & 0.282 & 0.129 & 0.837 & -0.052 & -0.334 & 0.23 & 0.142 & 0.714 \\
\hline
\end{tabular}

${ }^{1}$ Regression coefficient; ${ }^{2}$ Significant p-value: ${ }^{*} \mathrm{p}<0.05 ;{ }^{* * *} \mathrm{p}<0.01 ;{ }^{* * *} \mathrm{p}<0.001 ;{ }^{3}$ Std.Error; ${ }^{4}$ Confidence Intervals.

In addition, the domestic product (GDP) per inhabitant of Luxembourg (105,438\$ vs. USA 47,199\$ in 2010) [22] may give them hope to obtain job opportunities easier than their peers without a university degree. In this context the belief that a degree will guarantee not just a job but a "very good job" [25] [26] could affect their happiness and life satisfaction much more before they become aware of the mismatch and difficulty of the labour market [27].

For the students, career adaptability and career optimism predicted both, happiness and life satisfaction. For graduates only the career optimism attitudes were associated with the better happiness. In line with this invidious who have developed adaptability attitudes may increasingly feel able to manage and control themselves important aspects of their lives, be more likely to be satisfied with their achievement [28], be able to make the mark being more active in creating strategies to cope with their anxiety and fears [29] and could easier prepare their abilities to find suitable employment at times of uncertainty. According to these issue students with the higher career adaptability could be more able to handle their stressful period then the others by planning their 
career outcome and handling with a university workload, impacting their happiness and life satisfaction. Those attitudes should be promoted as early as possible to favor the strengthening of individual resources long before students have to cope with a professional transition [30].

For the graduates, having in mind that the majority of the sample had job, career adaptabilities may be relevant output for their future career, especially in transitions form unemployment to reemployment and perhaps only in the in the precarious situation career adaptability may positively influence sense of perception over one's own life wellbeing. In addition an optimistic individual may be more interested in their career future [31] and were more confident that their entirety of their life been close to their ideal. In this context we suggest that optimistic students and graduates may be more enthusiastically engages in their goal oriented career outcome. In addition each step toward the career objective may be perceived by invidious as an appropriate path for career success.

For the both samples, better health satisfaction was linked to greater happiness and life satisfaction. Young people who had a better general health perception had a greater psychological quality of life which is associated with acquisition of skills that increase employability [32] The perception of health satisfaction especially by young adult may not be characterised by illness but more positive feelings about themselves such an optimistic vision of the future and abilities and resources that allow them to cope with everyday difficulties. The relationships suggest that health satisfaction level is an important factor influencing the wellbeing of students and graduates which may help them to explore ways of gaining greater satisfaction from this important aspect of their life.

\section{Conclusion}

Master students and graduates had alterations in happiness and life satisfaction that were related to socioeconomic and perceived health difficulties, and positive career attitudes. Given the important role played in people's happiness and wellbeing, university career services should pay a particular attention in monitoring of the various components of positive career attitudes and encouraging experience opportunity and activities useful to offer young people a growing sense of hope and planning for the future. As recommendations, we proposed to elaborate interventions aiming at improving psycho-educational determinants. It must be stimulated at the beginning of the entry at the university with appropriately collaborative supports, pedagogical workshops and interpersonal trainings [30]. These findings may help with the development of university and post university services with the aim to increase happiness and life satisfaction among postgraduates' students and ex-students. In the context of developing a European Higher Educational Area, these measurements are major indicators that can be used as a guide to promote programs geared towards counselling, improvement of the social environment, and services to assist with university work and facilitate achievement of future professional projects [32].

\section{Acknowledgements}

Thanks to: All the volunteer students and graduates without whom this research could not have been undertaken. The project 2013-2016 untitled “CAPJOB-Students and graduates Capital employability and quality of life” was supported by a financial grant from the University of Luxembourg and a relevant technical help provided by CEDIES.

\section{References}

[1] European Foundation for the Improvement of Living and Working Conditions (2012) Quality of Life in Europe: Impacts of the Crisis. http://www.eurofound.europa.eu/pubdocs/2012/64/en/1/EF1264EN.pdf

[2] Frey, B.S. and Stutzer, A. (2002) Happiness and Economics: How the Economy and Institutions Affect Well-Being. Princeton University Press, Princeton, NJ. http://dx.doi.org/10.1111/1468-0297.13918

[3] Lane, R.E. (2000) The Loss of Happiness in Market Democracies. Yale University Press, New Haven, CT. http://dx.doi.org/10.1002/aps.80

[4] Lyubomirsky, S. and Tucker, K.L. (1998) Implications of Individual Differences in Subjective Happiness for Perceiving, Interpreting, and Thinking About Life Events. Motivation Emotion, 22, 155-186. http://dx.doi.org/10.1023/A:1021396422190

[5] Campbell, A., Converse, P.E. and Rodgers, W.L. (1976) The Quality of American Life. Russell Sage, New York.

[6] Gundelach, P. and Kreiner, S. (2004) Happiness and Life Satisfaction in Advanced European Countries. Cross-Cultural Research, 38, 359-386. http://dx.doi.org/10.1177/1069397104267483 
[7] OECD (2011) How Many Young People Graduate from Tertiary Education? In Education at a Glance: Highlights, OECD Publishing. http://dx.doi.org/10.1787/eag_highlights-2011-7-en

[8] Eurostat (2011) Labour Market Statistics—Eurostat-Europa. http://epp.eurostat.ec.europa.eu/cache/ITY_OFFPUB/KS-32-11-798/EN/KS-32-11-798-EN.PDF

[9] D’Ambrosio, C. (2012) Economic Insecurity and Individual Well-Being. Keio Economic Studies, 48, 127-129. http://hdl.handle.net/10993/15830

[10] Creed, P.A., Fallon, T. and Hood, M. (2009) The Relationship between Career Adaptability, Person and Situation Variables, and Career Concerns in Young Adults. Journal of Vocational Behavior, 74, 219-229. http://dx.doi.org/10.1016/j.jvb.2008.12.004

[11] Jameson, S. and Holden, R. (2000) Graduateness-Who Cares? Graduate Identity in Small Hospitality Firms. Education Training, 42, 264-271. http://dx.doi.org/10.1108/00400910010373714

[12] Roberts, R., Golding, J., Towell, T. and Weinreib, I. (1999) The Effects of Economic Circumstances on British Students’ Mental and Physical Health. Journal of American College Health, 48, 103-109. http://dx.doi.org/10.1348/135910700168928

[13] Spitz, E., Costantini, M.L. and Baumann, M. (2007) Adaptation and Strategies of Coping of the Students in First Academic Year. Revue Francophone du Stress et Trauma, 7, 217-225. http://hdl.handle.net/10993/1813

[14] Verger, P., Guagliardo, V., Gilbert, F., Rouillon, F. and Kovess-Masfety, V. (2010) Psychiatric Disorders in Students in Six French Universities: 12-Month Prevalence, Co Morbidity, Impairment and Help-Seeking. Social Psychiatry Psychiatric Epidemiology, 45, 189-199. http://dx.doi.org/10.1007/s00127-009-0055-z

[15] De Cuyper, N., de Jong, J., De Witte, H., Isaksson, K., Rigotti, T. and Schalk, R. (2007). Literature Review of Theory and Research on the Psychological Impact of Temporary Employment: Towards a Conceptual Model. International Journal of Management Reviews, 10, 25-51. http://dx.doi.org/10.1111/j.1468-2370.2007.00221.x

[16] Flum, H. and Blustein, D. L. (2000) Reinvigorating the Study of Exploration: A Conceptual Framework for Research. Journal of Vocational Behavior, 56, 380-404. http://dx.doi.org/10.1006/jvbe.2000.1721

[17] Savickas, M.L. and Porfeli, E.J. (2012) Career Adapt-Abilities Scale: Construction, Reliability and Measurement Equivalence across 13 Countries. Journal of Vocational Behaviour, 80, 661-673. http://dx.doi.org/10.1016/j.jvb.2012.01.012

[18] Rottinghaus, P.J., Day, S.X. and Borgen, F.H. (2005) The Career Futures Inventory: A Measure of Career-Related Adaptability and Optimism. Journal of Career Assessment, 13, 3-24. http://dx.doi.org/10.1177/1069072711420849

[19] Pouyaud, J., Vignoli, E., Dosnon, O. and Lallemand, N. (2012) Career Adapt-Abilities Scale France form: Psychometric properties and relationships to anxiety and motivation. Journal of Vocational Behaviour, 80, 692-697. http://dx.doi.org/10.1016/j.jvb.2012.01.021

[20] Trunzo, J.J. and Pinto, B.M. (2003) Social Support as a Mediator of Optimism and Distress in Breast Cancer Survivors. Journal of Consulting and Clinical Psychology, 71, 805-811. http://dx.doi.org/10.1037/0022-006X.71.4.805

[21] Coetzee, M. and Esterhuizen, K. (2010) Psychological Career Resources and Coping Resources of the Young Unemployed African Graduate: An Exploratory Study. SA Journal of Industrial Psychology, 36, 868-877. http://dx.doi.org/10.4102/sajip.v36i1.868

[22] The World Bank (2011) GDP per Inhabitant. http://donnees.banquemondiale.org/indicateur/NY.GDP.PCAP.CD

[23] Skevington, S.M., Lotfy, M. \& O’Connell, K.A. (2004) The World Health Organization's WHOQOL-BREF Quality of Life Assessment: Psychometric Properties and Results of the International Field Trial-A Report from the WHOQOL Group. Quality of Life Research, 13, 299-310. http://dx.doi.org/10.1023/B:QURE.0000018486.91360.00

[24] Helliwell, J., Layard, R. and Sachs, J. (2012) World Happiness Report. Centre for Economic Performance. Canadian Institute for Advanced Research \& The Earth Institute Columbia University, USA. http://www.earth.columbia.edu/sitefiles/file/Sachs\%20Writing/2012/World\%20Happiness\%20Report.pdf

[25] Stewart, J. and Knowles, V. (2000) Graduate Recruitment and Selection Practices in Small Businesses. Career Development International, 5, 21-38. http://dx.doi.org/10.1108/13620430010309332

[26] Stewart, J. and Knowles, V. (2000) Graduate Recruitment and Selection: Implications for HE, Graduates and Small Business Recruiters. Career Development International, 5, 65-80. http://dx.doi.org/10.1108/13620430010318909

[27] Rae, D. (2008) Riding out the Storm: Graduates, Enterprise and Careers in Turbulent Economic Times. Education Training, 50, 748-763. http://dx.doi.org/10.1108/00400910810917118

[28] Judge, T.A. (2009) Core Self-Evaluations and Work Success. Current Directions in Psychological Science, 18, 58-62. http://dx.doi.org/10.1111/j.1467-8721.2009.01606.x

[29] Bayram, N. and Bilgel, N. (2008) The Prevalence and Socio-Demographic Correlations of Depression, Anxiety and Stress among a Group of University Students. Social Psychiatry Psychiatric Epidemiology, 43, 667-672. 
http://dx.doi.org/10.1371/annotation/e6648eb3-37d6-44d7-8052-979af14fa921

[30] Karavdic, S. and Baumann, M. (2014) What Factors Can Enhance Dynamic Career Attitudes of University Students? In: Pracana, C., Ed., International Psychological Applications Conference and Trends, World Institute for Advanced Research and Sciences, WIARS, Lisbon, 209-212. http://hdl.handle.net/10993/16378

[31] McIlveen, P., Beccaria, G. and Burton, L.J. (2013) Beyond Conscientiousness: Career Optimism and Satisfaction with Academic Major. Journal of Vocational Behavior, 83, 229-236. http://dx.doi.org/10.1016/j.jvb.2013.05.005

[32] Baumann, M., Ionescu, I. and Chau, N. (2011) Psychological Quality of Life and Its Association with Academic Employability Skills among Newly-Registered Students from Three European Faculties. BMC Psychiatry, 11, 63. http://www.biomedcentral.com/1471-244X/11/63. 